\title{
$\mathrm{AZ}$ 系 $\mathrm{Mg}$ 合金の自然浸漬環境下における 腐食特性に及ぼす $\mathrm{Al}$ 含有量の影響
}

\author{
川村 貴 人 $^{1, *} \quad$ 砂 田 $\quad$ 聡 $^{2} \quad$ 能登谷久公 $3 \quad$ 近 藤 勝 義 $4 \quad$ 真 島一 彦 2
}

\author{
1富山大学大学院理工学教育部 \\ 2 富山大学大学院理工学研究部 \\ 3株式会社高松メッキ \\ ${ }^{4}$ 大阪大学接合科学研究所
}

J. Japan Inst. Metals, Vol. 72, No. 3 (2008), pp. 216-223

(C) 2008 The Japan Institute of Metals

\section{Influence of Al Content on Corrosion Characteristics of AZ Series Mg Alloys}

Takahito Kawamura ${ }^{1, *}$, Satoshi Sunada ${ }^{2}$, Hisakimi Notoya ${ }^{3}$, Katsuyoshi Kondo ${ }^{4}$ and Kazuhiko Majima²

${ }^{1}$ Graduate School of Science and Engineering for Education, University of Toyama, Toyama 930-8555

${ }^{2}$ Graduate School of Science and Engineering for Research, University of Toyama, Toyama 930-8555

${ }^{3}$ Takamatsu Plating Co. ltd., Toyama 939-2366

${ }^{4}$ Joining and Welding Research Institute, Osaka University, Osaka 567-0047

Though Mg alloys are the outstanding candidates for the use in automotive, aerospace and electronic industries because of their low density and excellent strength to weight ratio, they have a great disadvantage in corrosion resistance. In this study, their corrosion behavior has been investigated by the polarization test and electrochemical impedance spectroscopy test for their practical use. AZ series $\mathrm{Mg}$ alloy samples produced by conventional ingot metallurgy showed a little slight decrease $E_{\text {corr }}$ with an increase of Al content, while they indicated a remarkable decrement of $I_{\text {corr }}$ with increasing amount of Al content.

(Received October 16, 2007; Accepted January 7, 2008)

Keywords: polarization curve, electrochemical impedance spectroscopy, $\mathrm{Na}_{2} \mathrm{SO}_{4}$ solution, Evans diagram

\section{1. 緒言}

$\mathrm{Mg}$ 合金は実用合金中では最軽量であることから，携帯用 端末の構造材等の軽量化が求められる製品を生産する上で非 常に有用である.さらに，高い比強度を持つことから，自動 車産業や航空宇宙産業等の多方面で $\mathrm{Al}$ 系合金や鉄系合金の 優位的代替材料として期待されている.

上記のように $\mathrm{Mg}$ 合金は比強度が高いという有利な特性 を有するが，電気化学的には非常に活性な金属であることか ら，腐食による制約が実用化への大きな問題となっており解 決策が求められている。しかしながら, 本合金の活性な性質 上, 電気化学的な測定や腐食特性の評価が難しく, 腐食に関 する研究報告1)はまだ少ないのが現状である.

そこで, 本研究では $\mathrm{Mg}$ 合金の中でも機械的特性に優 れ, 一般構造材料として用いられる $\mathrm{Mg}-\mathrm{Al}-\mathrm{Zn}$ 系合金 (以降 $\mathrm{AZ}$ 系合金と略記する)に焦点を当て，その腐食特性に及ぼ す添加元素の影響について調査することを目的とした，具体 的には，一般溶製法により作製された AZ31W, AZ61W， $\mathrm{A} Z 91 \mathrm{~W}$ 合金を用い，その腐食特性に及ぼす $\mathrm{Al}$ 含有量の影

\footnotetext{
* 富山大学大学院生 (Graduate Student, University of Toyama)
}

響について電気化学的な検討を行った.

\section{2. 実 験 方 法 \\ 2.1 試 料}

本実験には Table 1 に示した化学組成を有する AZ31W, AZ61W, AZ91Wの Mg 合金の一般溶製材を使用した.

電気化学的測定に用いた試験電極および乾湿繰返し試験に 用いた試料寸法はともに， $15 \mathrm{~mm} \times 20 \mathrm{~mm} \times 3 \mathrm{~mm}$ である. 測定の前処理として, 電極面を耐水エメリー紙 80～2000 番 を用いて順次研磨した後, アセトンを用いて脱脂, 洗浄し, 乾燥させた．このようにして得られた試料表面に電極面積 $1.0 \times 10^{-4} \mathrm{~m}^{2}$ を残して, シリコーンゴムで絶縁して供試電

Table 1 Chemical composition of the specimen used.

\begin{tabular}{ccccccccc}
\hline \multirow{2}{*}{ Specimen } & \multicolumn{7}{c}{ Chemical composition (mass\%) } \\
\cline { 2 - 10 } & $\mathrm{Mg}$ & $\mathrm{Al}$ & $\mathrm{Zn}$ & $\mathrm{Mn}$ & $\mathrm{Si}$ & $\mathrm{Cu}$ & $\mathrm{Fe}$ & $\mathrm{Ni}$ \\
\hline AZ31W & Bal. & 3.42 & 0.98 & 0.53 & 0.007 & 0.002 & 0.004 & 0.001 \\
\hline AZ61W & Bal. & 6.22 & 0.56 & 0.47 & 0.008 & 0.006 & 0.005 & 0.001 \\
\hline AZ91W & Bal. & 8.16 & 0.621 & 0.23 & 0.07 & - & 0.004 & - \\
\hline
\end{tabular}

Bal.: balance 
極とした。

\section{2 腐食溶液の調製}

本実験では活性金属の腐食試験にしばしば用いられてい る ${ }^{2}$ 濃度 2.5 mass $\%$ の $\mathrm{Na}_{2} \mathrm{SO}_{4}$ 水溶液を腐食溶液として用い た. $\mathrm{Na}_{2} \mathrm{SO}_{4}$ を $0.1 \mathrm{mg}$ 精度の精密電子天秤で秤量した。本 実験で用いた腐食溶液は特級試薬および電気伝導率が $2 \times$ $10^{-4} \mathrm{~S} \cdot \mathrm{m}^{-1}$ 以下の脱イオン水を用いて調製した.

\section{3 分極曲線測定}

上に示した 3 種類の $\mathrm{Mg}$ 合金の一般溶製材の基本的な腐 食特性を調べるために分極曲線を測定した．Fig. 1 には本実 験で用いた電気化学試験の実験装置の模式図を示した. 分極 曲線測定に用いた電解槽は内容積が $4 \times 10^{-4} \mathrm{~m}^{3}$ の $\mathrm{H}$ 字型セ ルである．測定中に対極での反応の影響を防ぐために，多孔 質ガラス製隔膜で区切られたアノード室およびカソード室を 有するものである.

分極曲線の測定は, 所定温度に保つため恒温槽中に保持し た電解槽に，あらかじめ高純度 $\mathrm{N}_{2}$ ガスで十分に脱酸素した 腐食溶液 $2 \times 10^{-4} \mathrm{~m}^{3}$ を入れ，試料電極を浸漬し， $1.8 \mathrm{ks}$ 間 保持した後, ポテンショスタットで各試料の $E_{\text {corr }}$ である $-1.5 \mathrm{~V}$ 付近からカソード側を測定する場合 $-2.0 \mathrm{~V}$ まで, アノード側を測定する場合 $-0.7 \mathrm{~V}$ まで電位走査速度 $0.5 \times$ $10^{-3} \mathrm{~V} \cdot \mathrm{s}^{-1}$ で走査し，その電位と電流密度の対数值を自動 記録させた.なお，すべての電気化学的計測は $\mathrm{N}_{2}$ ガス通気 中で行った．対極には $\mathrm{Pt}$ 電極を, 照合電極として $\mathrm{Ag} / \mathrm{AgCl}$ $\left(3.33 \mathrm{kmol} \cdot \mathrm{m}^{-3} \mathrm{KCl}\right)$ 電極を用いた。本報の電位は特に断ら ない限り $\mathrm{Ag} / \mathrm{AgCl}$ 電極電位を基準にして示した。なお, $\mathrm{Ag} / \mathrm{AgCl}$ 電極は温度 $298 \mathrm{~K}$ で標準水素電極電位に対し $+0.206 \mathrm{~V}$ である.

\section{4 電気化学インピーダンス分光法}

分極曲線測定によって得られた $\mathrm{AZ}$ 系合金の基本的な腐食 特性をより詳細に調べるため, 電気化学インピーダンス分光
法 (以降 EIS と略記する)による測定を行った. Fig. 1 に示 した実験装置の模式図は，北斗電工製の HZ-3000 型ポテン ショスタットによる定電位分極回路と, NF 回路製の 5080 型周波数応答解析器 (以降 FRA と略記する)を組み合わせた 電極インピーダンス測定装置から構成されている. FRA で 発生させた正弦波交流信号は，ポテンショスタットを介して 定電位分極下の試料電極に重䪶される. そのとき流れた交流 電流の大きさと位相を求め, 印加した電圧と比較しインピー ダンスを求めた．このインピーダンスを求める一連の過程は FRA に付属するコンピュータで自動的に行った.

電位規制による EIS 測定は, 分極曲線によって得られた カソード反応領域, およびアノード反応領域における腐食特 性を調査するため, 三電極法を用いて電位を各試料の $E_{\text {corr }}$ と $E_{\text {corr }} \pm 20 \mathrm{mV}, \pm 40 \mathrm{mV}, \pm 60 \mathrm{mV}, \pm 100 \mathrm{mV}, \pm 150 \mathrm{mV}$, $\pm 200 \mathrm{mV}$ の各電位にそれぞれ規制した. Fig. 2 に EIS 測定 時の設定電位の推移を模式的に示した. 本実験では, 各設定 電位における腐食特性を比較検討するため，定時間保持する ステップアップ法による EIS 測定を行った。図中の各ステ ップは各電位に拈ける電極の状態を安定させるため $1.8 \mathrm{ks}$ 間設定電位にて保持し，その後，電位を保持したまま $3.0 \mathrm{ks}$

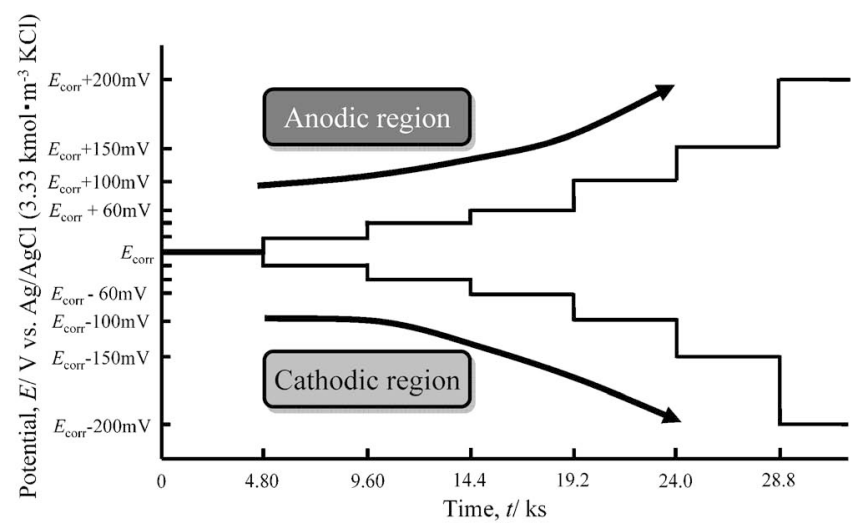

Fig. 2 Pattern diagram of transition of controlled potentials for EIS measurement.

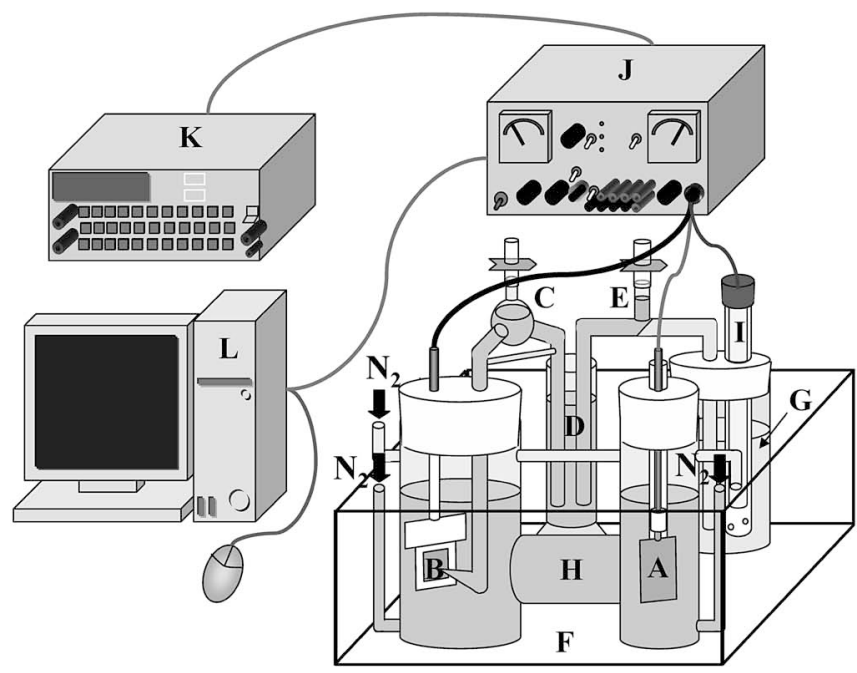

A : Counter electrode $(\mathrm{Pt})$

B : Specimen

$\mathrm{C}:$ Bridge

D : Intermediate beaker

E : Salt bridge

F : Water bath

$\mathrm{G}$ : Saturated potassium chloride solution $\mathrm{H}$ : Electrochemical cell I : Reference electrode

$\mathrm{J}:$ Potentiostat

$\mathrm{K}:$ FRA

L : Computer

Fig. 1 Experimental apparatus for electrochemical measurement. 
間 EIS 測定した。すなわち 1 つのステップは $4.8 \mathrm{ks}$ 間であ る. EIS 測定では，これらの設定電位に重畳する正弦波交流 電位の振幅を $1.0 \times 10^{-2} \mathrm{~V}$ とし， $1.0 \times 10^{5}$ から $1.0 \times 10^{-3}$ $\mathrm{Hz}$ までの周波数範囲において周波数が 10 倍変化する間に 5 点の周波数について測定した.

測定されたインピーダンス軌跡はインピーダンス線図上に

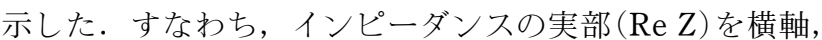
虚部 $(\operatorname{Im} Z)$ を縦軸とした複素平面上にプロットし，虚部の マイナス側を第 1,2 象限になるように示し, 電極インピー ダンス軌跡を描いた。したがって，第 $1 ， 2$ 象限は容量性リ アクタンスを示し，第 $3 ， 4$ 象限は誘導性リアクタンスを示 す. また，電極インピーダンス軌跡中には主な測定点に周波 数を記入した.

\section{5 乾湿繰返し試験}

日中の高温乾燥雲囲気および夜間の低温多湿度䨌囲気に代 表される実環境下ではこの 2 つ環境が繰り返されること によって腐食が進行することが大きな問題となっている．本 実験ではこのような実環境下を想定した実験として乾湿繰返 し試験を行い, 上記の電気化学的試験によって得られた $\mathrm{AZ}$ 系合金の腐食特性と比較検討した，試験溶液には本実験の電 気化学試験と同じ 2.5 mass \% の $\mathrm{Na}_{2} \mathrm{SO}_{4}$ の腐食溶液を用い た。試料は試験面 $1.0 \times 10^{-4} \mathrm{~m}^{2}$ を残してポリミドテープで 絶縁処理を施した．温度および湿度は日中を想定した高温乾 燥雲囲気として温度 $323 \mathrm{~K}$ 湿度 $10 \%$ の雾囲気と, 夜間を想 定した低温多湿度雾囲気として温度 $298 \mathrm{~K}$ 湿度 $80 \%$ の雾囲 気を採用した。

試験開始前に腐食溶液を $0.3 \times 10^{-6} \mathrm{~m}^{3}$ 滴下した後に低温 多湿度雲囲気に $43.2 \mathrm{ks}$ 間試料を保持した。その後 $43.2 \mathrm{ks}$ 間高温乾燥雾囲気に試料を保持した。これらの作業を合計 3 回繰返した，試験終了後は試料を十分に水洗，乾燥し，視覚 にて腐食の度合いおよび腐食形態を観察した。

\section{3. 実験結果および考察}

\section{1 分極曲線測定}

上記の AZ 系合金の腐食特性を調べるために分極曲線を測 定した. Fig. 3 には各試料のカソード分極曲線を示した. 電 位をアノード側からカソード側に掃引した場合，分極曲線測 定中に電流方向が反転する電位を $E_{\text {corr (a) }}$ とすると， $E_{\text {corr (a) }}$ は AZ31W では-1.55 V, AZ61W では-1.57 V, AZ91W で はー $1.60 \mathrm{~V}$ である。 $E_{\text {corr (a) }}$ より低電位のカソード領域で は，いずれの試料ともに $E_{\text {corr (a) }}$ より $0.05 \sim 0.15 \mathrm{~V}$ 低い電位 範囲で良好な Tafel 勾配を示し, $-1.70 \mathrm{~V}$ 以下の電位で限界 電流的挙動を示した. Fig. 4 には各試料のアノード分極曲線 を示した。電位をカソード側からアノード側に掃引した場 合，分極曲線測定中に電流方向が反転する電位を $E_{\text {corr (c) }}$ と すると， $E_{\text {corr(c) }}$ は $\mathrm{AZ} 31 \mathrm{~W}$ では $-1.50 \mathrm{~V}, \mathrm{AZ} 61 \mathrm{~W}$ では $-1.53 \mathrm{~V}, \mathrm{AZ} 91 \mathrm{~W}$ ではー $1.57 \mathrm{~V}$ であり，-1.45 V 付近で肩 を持つような特徵的な挙動を示した。 続いて, 電位が- 1.30 〜 - $1.25 \mathrm{~V}$ で $\mathrm{AZ} 31 \mathrm{~W}$ は他の 2 つの試料と比較して電流密 度が減少する挙動を示した。この電流密度の減少についての

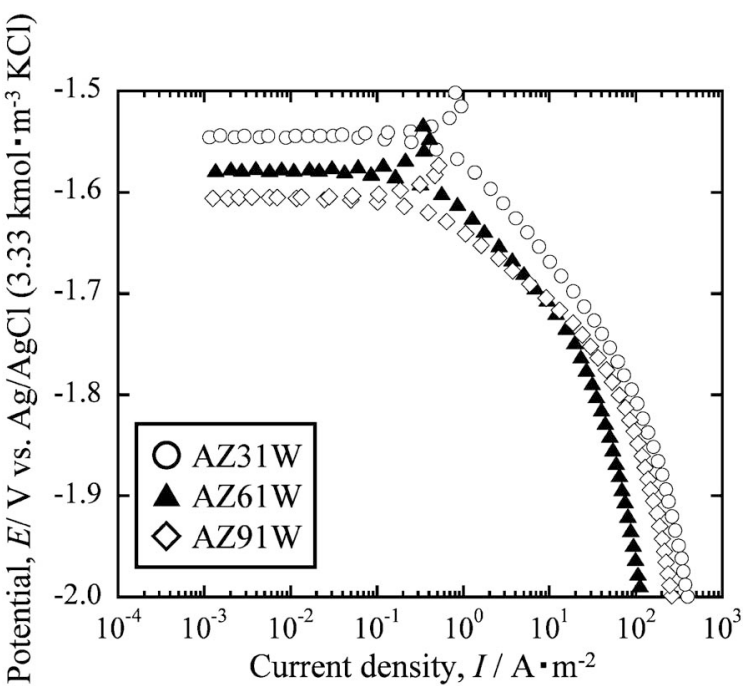

Fig. 3 Cathodic polarization curves of $\mathrm{AZ}$ series $\mathrm{Mg}$ alloys measured in 2.5 mass $\% \mathrm{Na}_{2} \mathrm{SO}_{4}$ solution at $298 \mathrm{~K}$.

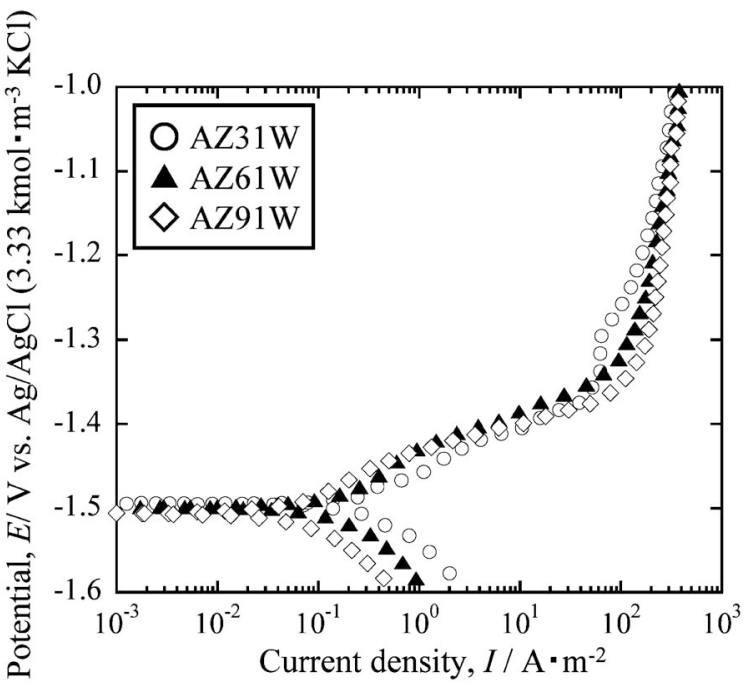

Fig. 4 Anodic polarization curves of $\mathrm{AZ}$ series $\mathrm{Mg}$ alloys measured in 2.5 mass $\% \mathrm{Na}_{2} \mathrm{SO}_{4}$ solution at $298 \mathrm{~K}$.

詳細は電極インピーダンスの解析と併せて 3.3 節に述べる. さらに貴な $-1.20 \mathrm{~V}$ 以上の電位範囲では 3 つの試料ともに 約 $3.5 \times 10^{2} \mathrm{~A} \cdot \mathrm{m}^{-2}$ の電流密度を示し限界電流的挙動を示し た。

Fig. 3 で示したカソード領域および Fig. 4 で示したア ノード領域では，ともに各試料で分極曲線に違いがある結果 が得られた．そこで，これらの違いを検討するため，添加元 素である $\mathrm{Al}$ 含有量の影響について調べた.

Fig. 3 に示したカソード分極曲線では，電位 -1.55 - $1.68 \mathrm{~V}$ の範囲で AZ31W に対し，AZ61W, AZ91W の電 流密度が小さく, カソード分極曲線は $\mathrm{Al}$ 含有量の増加に伴 い分極する傾向を示した。 さらに，Fig. 4 に示したアノード 分極曲線では，電位 $-1.50 \sim-1.45 \mathrm{~V}$ の範囲で $\mathrm{AZ3} 1 \mathrm{~W} に$ 対し, AZ61W, AZ91W の電流密度が小さく, アノード分極 曲線も $\mathrm{Al}$ 含有量の増加に伴い分極する傾向を示した．この ような結果から， $\mathrm{AZ}$ 系合金の腐食特性は $\mathrm{Al}$ 含有量によっ 
てカソード反応およびアノード反応の規模が異なると考えら れる，そこで，自然浸漬時に抢ける腐食速度をTafel 外挿法 を用いて腐食電流密度 $I_{\text {corr }}$ を算出し, 比較検討した。

Fig. 5 には腐食電流密度 $I_{\text {corr }}$ に及ぼす $\mathrm{Al}$ 含有量の影響を 示した. 各試料の $I_{\text {corr }}$ は $\mathrm{AZ} 31 \mathrm{~W}$ が $0.70 \sim 0.88 \mathrm{~A} \cdot \mathrm{m}^{-2}$, $\mathrm{AZ61W}$ が $0.39 \sim 0.45 \mathrm{~A} \cdot \mathrm{m}^{-2}, \mathrm{AZ91W}$ が $0.19 \sim 0.32 \mathrm{~A} \cdot \mathrm{m}^{-2}$ を示した． Fig. 5 のように， $\mathrm{Al}$ 含有量が増加するに伴い $I_{\text {corr }}$ が低下する傾向を示した．合金化による $\mathrm{Al}$ 含有量が自 然浸漬時における腐食速度を減少させることが明確になった.

Fig. 5 に示した $\mathrm{Al}$ 含有量の増加による $I_{\text {corr }}$ の減少が，力 ソード反応，アノード反応のどちらの抑制に起因しているか 明らかにするため, Fig. 6 には $E_{\text {corr (a) }}$ に及ぼす $\mathrm{Al}$ 含有量の

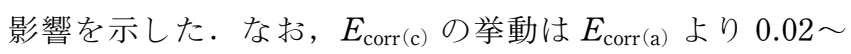
$0.04 \mathrm{~V}$ 高い值を示すが, $\mathrm{Al}$ 含有量による影響は同一傾向を

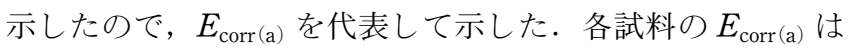
$\mathrm{AZ31W}$ が $-1.56 \sim-1.54 \mathrm{~V}, \mathrm{AZ} 61 \mathrm{~W}$ が $-1.58 \sim-1.56 \mathrm{~V}$,

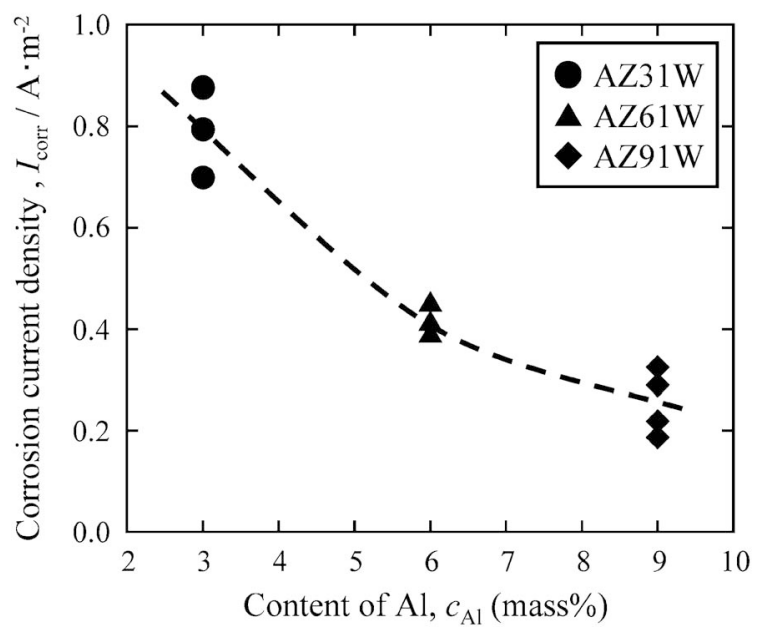

Fig. 5 Influence of $\mathrm{Al}$ content on corrosion current density for $\mathrm{AZ}$ series $\mathrm{Mg}$ alloys.

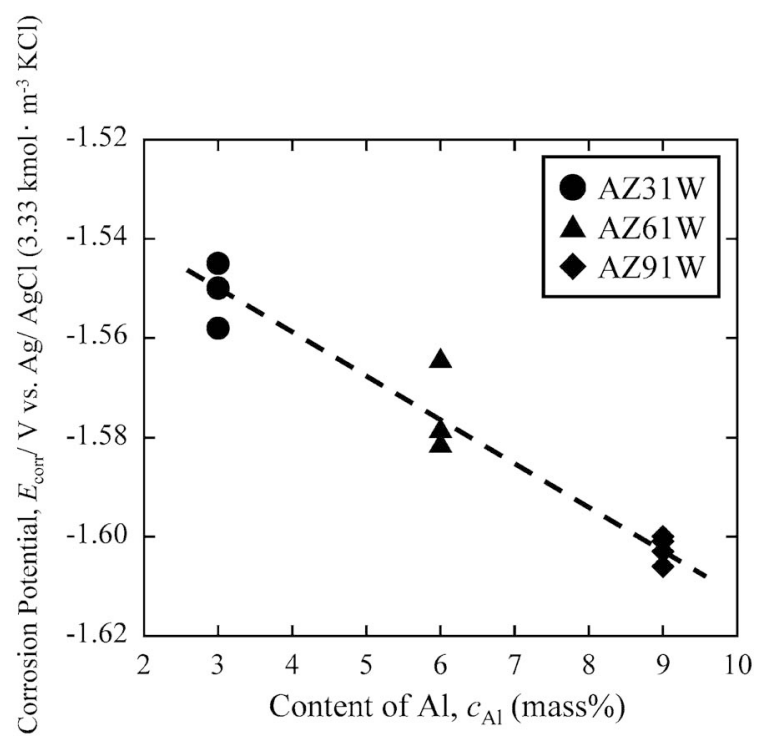

Fig. 6 Influence of $\mathrm{Al}$ content on corrosion potential for $\mathrm{AZ}$ series $\mathrm{Mg}$ alloys.
AZ91W がー1.61〜 - 1.60 V を示し，Fig. 6 中の直線で示す ように $\mathrm{Al}$ 含有量を増加により $E_{\text {corr (a) }}$ がわずかに低くなる傾 向が見られた. Fig. 5 と Fig. 6 の結果を後述の Evans の分 極特性図より考え合わせると, Al 含有量の増加に伴い力 ソード反応とアノード反応の両者の抑制が $\mathrm{AZ}$ 系 $\mathrm{Mg}$ 合金の 自然浸漬時における腐食速度を減少させるが，その抑制効果 はカソード反応が顕著であると考えられる.

このことを詳細に示すため, Fig. 7 には Evans の分極特 性図を用いて本実験で得られた分極曲線の模式図を示した。

$\mathrm{Al}$ 含有量の増加に伴って $I_{\text {corr }}$ が大きく減少し， $E_{\text {corr }}$ がわず かに低下する傾向を示したことから, カソード反応の抑制と ともにアノード反応のわずかな抑制が起こっているものと考 えられる. アノード反応の抑制は, $\mathrm{Mg}$ 合金の場合, 保護皮 膜の形成によることが報告されている33 が，この場合保護皮 膜上でのアノード反応，カソード反応の特性を表しているも のと考えられる.したがって, AZ 系合金の腐食特性には $\mathrm{Al}$ 含有量が大きく影響を及ぼし, 自然浸漬環境下に捛ける耐食 性が大きく変化するものと考えられる．これらの分極曲線測 定によって得られた傾向をより詳細に検討するため, EIS 測 定を行った.

\section{2 電気化学インピーダンス解析}

分極曲線測定によって得られた分極曲線上で特徵的な挙動 を示した電位で EIS 測定を行った. 得られたインピーダン 又軌跡の一例として AZ31Wの $E_{\text {corr }}$ に規制した電気化学イ ンピーダンス軌跡の模式図を Fig. 8 に示す.

得られた電気化学インピーダンス軌跡は, 周波数 $1.0 \times$ $10^{5} \mathrm{~Hz}$ から $1.0 \times 10^{-1} \mathrm{~Hz}$ の範囲で容量性の半円を第 1 象限 に示した. また, $1.0 \times 10^{-1} \mathrm{~Hz}$ から $1.0 \times 10^{-2} \mathrm{~Hz}$ 付近の周 波数範囲では第 1 象限に 2 つ目の容量性の半円を示した. 続いて, $1.0 \times 10^{-2} \mathrm{~Hz}$ から $1.0 \times 10^{-3} \mathrm{~Hz}$ の周波数範囲では 第 4 象限に誘導性の半円を示した.

第 1 象限に見られる容量性半円は電荷移動抵抗 (Charge transfer resistance : 以降 $R_{\mathrm{ct}}$ と略記する) と電気二重層容量 (Double layer capacitance : 以降 $C_{\mathrm{dl}}$ と略記する) からなる軌 跡である. また，それに続く 2 つ目の容量性半円は $\mathrm{Mg}$ 合

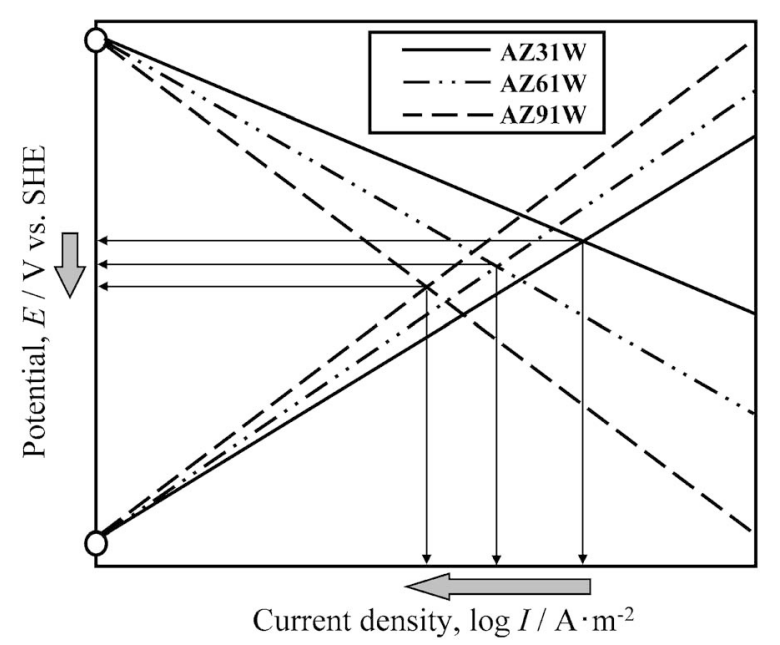

Fig. 7 Evans diagram for polarization of $\mathrm{AZ}$ series $\mathrm{Mg}$ alloys. 
金表面に形成される保護皮膜3)の形成に関するものであり， 第 4 象限に見られる誘導性半円は, 保護皮膜の溶解に関す る吸着中間体を経由したアノード溶解反応によるものと考え られる。

電荷移動過程における吸着中間体を伴うインピーダンス軌 跡は，杉本 ら ${ }^{4-6)}$, Epelboin $5^{7-9)}$, Armstrong ら ${ }^{10-12)}$,

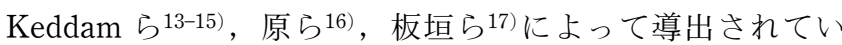
る.それらを参考にして杉本 ${ }^{18)}$ の導出方に基づき, 砂田ら は式 ( 1 )を導いた ${ }^{19)}$. 実測のインピーダンス軌跡とこの式 (1)によって計算されるインピーダンス軌跡が一致するよ うに各パラメータの值を試行錯誤法により決定した.

$$
\frac{1}{Z}=\frac{1+\left(j \omega \tau_{0}\right)^{\gamma}}{R_{\mathrm{ct}}}+\sum_{\mathrm{i}=1}^{n} \frac{1}{R_{\mathrm{i}}\left(1+j \omega \tau_{\mathrm{i}}\right)}
$$

ここで $Z$ は電気化学インピーダンス, $j$ は虚数単位, $\omega$ は 規制電位に重畳する交流成分の角速度, $\tau_{0}$ は $R_{\mathrm{ct}}$ と $C_{\mathrm{dl}}$ の積, $\gamma$ は $0<\gamma \leqq 1$ の範囲内で变化する電極の面荒さ20)等に起因す る補正パラメータである. 右辺の 2 項目は, 主に誘導性半 円を示す吸着中間体による軌跡を示すが，本試料からは安定 した電気化学インピーダンスが得られないため，この部分の 解析は今後の課題としてさらに検討することにした.

上記の方法で各電位における電気化学インピーダンス軌跡 から $R_{\mathrm{ct}}, C_{\mathrm{dl}}, \tau_{0}$ の各パラメータを決定した.

\section{$3.3 R_{\mathrm{ct}}, C_{\mathrm{dl}}, \tau_{0}$ に及ぼす電位の影響}

電位を各試料の $E_{\text {corr }}$ と, 分極曲線上で特徵的な挙動を示 した $E_{\text {corr }} \pm 20 \mathrm{mV}, \pm 40 \mathrm{mV}, \pm 60 \mathrm{mV}, \pm 100 \mathrm{mV}, \pm 150$ $\mathrm{mV}, \pm 200 \mathrm{mV}$ の各電位で EIS 測定を行い, 得られたイン ピーダンス軌跡を比較検討した。

Fig. 9 にはカソード領域で得られたインピーダンス軌跡の 内, 代表的なものとして Fig. 9 (a)に各試料の $E_{\text {corr, Fig. }}$. 9 (b)に各試料の $E_{\text {corr }}-20 \mathrm{mV}$, Fig. 9 (c) に各試料の $E_{\text {corr }}$ $-100 \mathrm{mV}$ におけるインピーダンス軌跡を示した. $E_{\text {corr }}$ およ び $E_{\text {corr }}-20 \mathrm{mV}$ におけるインピーダンス軌跡では $\mathrm{Al}$ 含有量 の増加に伴い高周波側の容量性半円の直径の大きさが大きく なり，高周波側の容量性半円に続き，2つ目の容量性半円お よびそれに続く誘導性半円が見られた.しかしながら，それ

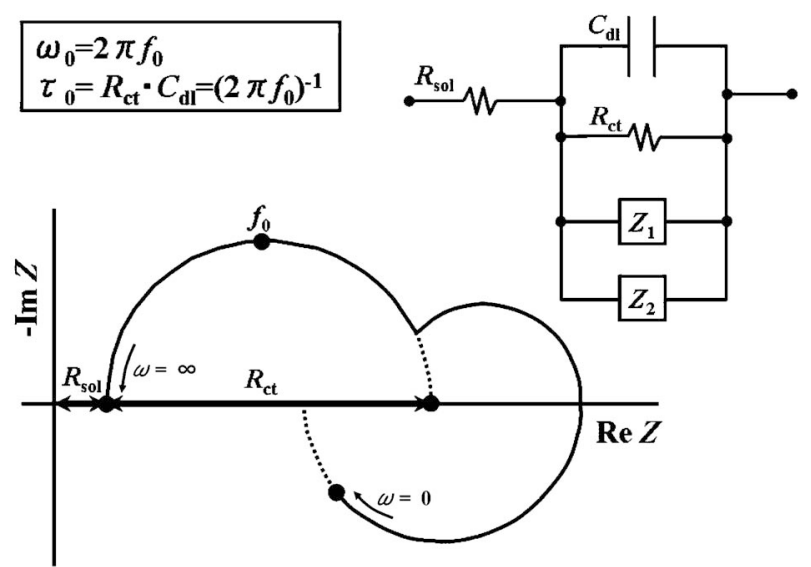

Fig. 8 Pattern diagram of impedance diagram of AZ31W measured under $E_{\text {corr }}$.
以下の電位では $E_{\mathrm{corr}}-100 \mathrm{mV}$ のように, 2 つ目の容量性半 円や誘導性半円は非常に小さくなった．このことから， $E_{\text {corr }}$ $-20 \mathrm{mV}$ 以下の電位では保護皮膜の形成反応 ${ }^{3)}$ が小さくなっ ていることが考えられる.

Fig. 10 にはアノード領域で得られたインピーダンス軌跡 の内，代表的なものとして Fig. 10 (a)に各試料の $E_{\text {corr }}$, Fig. 10 (d)に各試料の $E_{\text {corr }}+20 \mathrm{mV}$, Fig. 10 (e)に各試料の $E_{\text {corr }}$ $+60 \mathrm{mV}$ に打けるインピーダンス軌跡を示した. 各イン ピーダンス軌跡とも $\mathrm{Al}$ 含有量の増加に伴い高周波側の容量 性半円の直径の大きさが大きくなり, 高周波側の容量性半円 に続き, 2 つ目の容量性半円およびそれに続く誘導性半円が 見られた. 一方, 各試料で高周波側の容量性半円の大きさは 電位によって大きく変化して抢り, 試料表面での電荷移動に 対する抵抗が電位によって大きく变化していると考えられ る. そこで, 3.2 節に示した試行錯誤法を用いて $R_{\mathrm{ct}}, C_{\mathrm{dl}}, \tau_{0}$ を決定し，それらに及ぼす電位の影響について検討した。

Fig. 11 に $R_{\mathrm{ct}}$ に及ぼす電位の影響を示した。各試料の

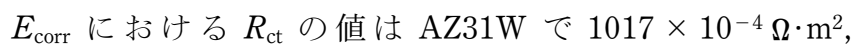
AZ61W で $1518 \times 10^{-4} \Omega \cdot \mathrm{m}^{2}, \mathrm{AZ91W}$ で $1828 \times 10^{-4} \Omega \cdot \mathrm{m}^{2}$ であったすすなわち，自然浸漬環境下における試料表面での 電荷移動に対する抵抗が $\mathrm{Al}$ 含有量の増加に伴い増加してい る.このことは, 先に Fig. 5 で示した自然浸漬環境下での
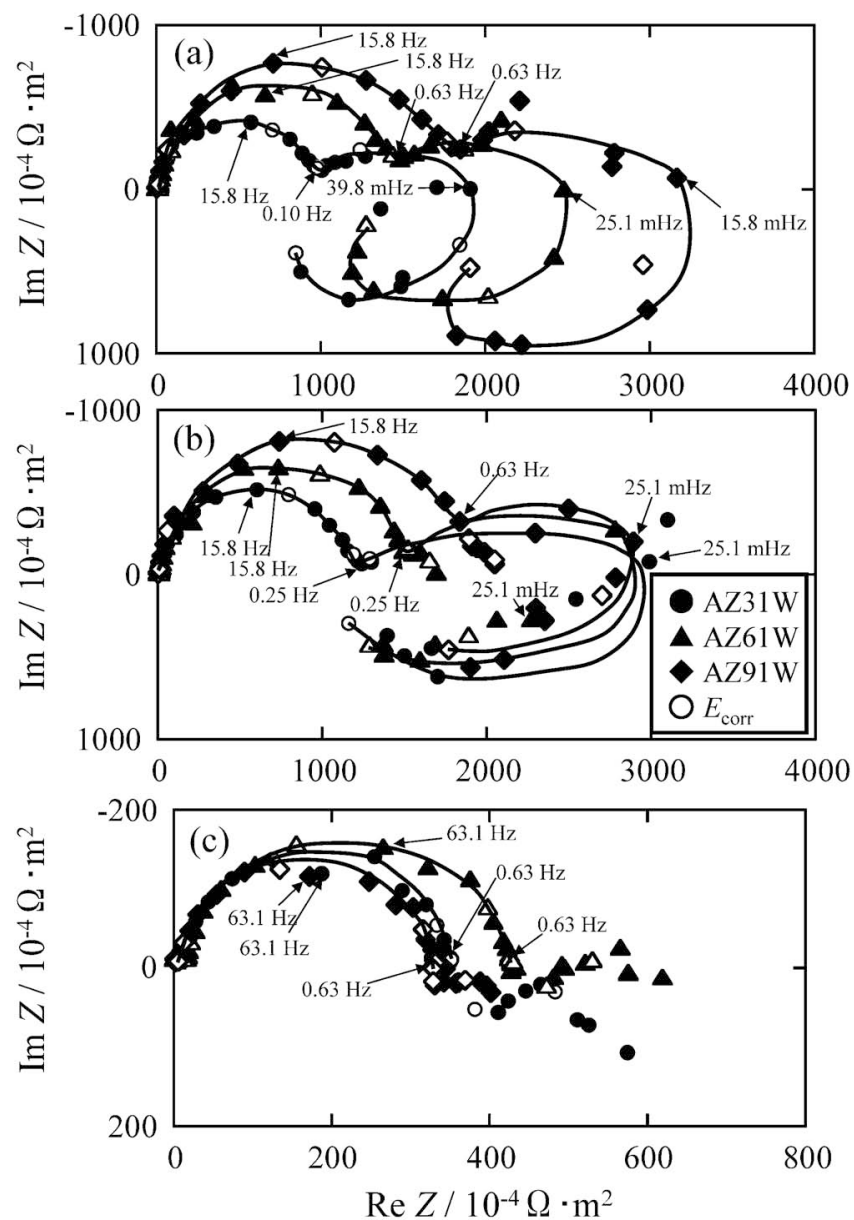

Fig. 9 Impedance diagrams of $\mathrm{AZ}$ series $\mathrm{Mg}$ alloys measured under various potentials. (a) $E_{\text {corr }}$, (b) $E_{\text {corr }}-20 \mathrm{mV}$, (c) $E_{\text {corr }}$ $-100 \mathrm{mV}$. 
腐食速度に及ぼす $\mathrm{Al}$ 含有量の関係と良好な一致を示してい る.

$$
\text { 一方, カソード反応領域では } E_{\mathrm{corr}}-20 \mathrm{mV} \text { での } R_{\mathrm{ct}} \text { は, }
$$
$E_{\text {corr }}$ に比較してわずかな増加が見られた。このときの $R_{\mathrm{ct}}$ の 值は AZ31W で $1236 \times 10^{-4} \Omega \cdot \mathrm{m}^{2}, \mathrm{AZ} 61 \mathrm{~W}$ で $1598 \times 10^{-4}$ $\Omega \cdot \mathrm{m}^{2}, \mathrm{AZ91W}$ で $1958 \times 10^{-4} \Omega \cdot \mathrm{m}^{2}$ であった，また，前述の ように $E_{\mathrm{corr}}-20 \mathrm{mV}$ のインピーダンス軌跡には皮膜形成に
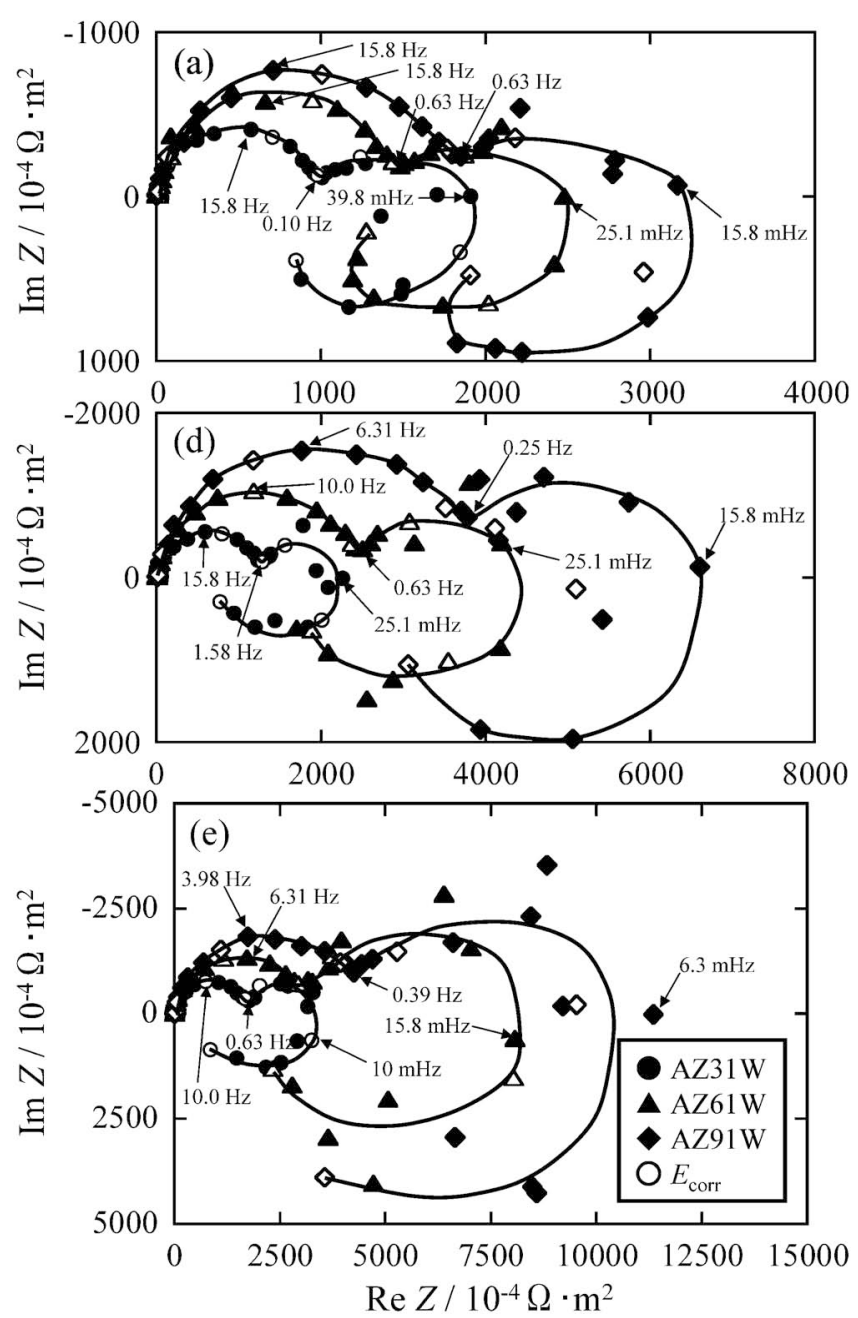

Fig. 10 Impedance diagrams of $\mathrm{AZ}$ series $\mathrm{Mg}$ alloys measured under various potentials. (a) $E_{\text {corr }}$, (d) $E_{\text {corr }}+20 \mathrm{mV}$, (e) $E_{\text {corr }}$ $+60 \mathrm{mV}$.
関与すると考えられる 2 つ目の容量性半円やそれに続く誘 導性半円が確認されていることから， $E_{\text {corr }}$ に近いカソード 領域に颃いて保護皮膜の形成が起こっているものと考えられ る.

また，アノード反応領域では $R_{\mathrm{ct}}$ の大幅な増加が見られ た。これは，アノード反応によって溶出した $\mathrm{Mg}^{2+}$ イオン が保護皮膜の形成に関与しているためではないかと考えられ る.なお，アノード反応領域では $R_{\mathrm{ct}}$ が $E_{\mathrm{corr}}+60 \mathrm{mV}$ 付近 で最大值を示した．このときの各試料の $R_{\mathrm{ct}}$ の值は $\mathrm{AZ} 31 \mathrm{~W}$ で $1772 \times 10^{-4} \Omega \cdot \mathrm{m}^{2}, \mathrm{AZ61W}$ で $3167 \times 10^{-4} \Omega \cdot \mathrm{m}^{2}, \mathrm{AZ91W}$ で $4692 \times 10^{-4} \Omega \cdot \mathrm{m}^{2}$ であった．この $R_{\mathrm{ct}}$ のピークを過ぎる と電位のわずかな上昇で $R_{\mathrm{ct}}$ が急激に減少する挙動を示した ことから，合金表面で孔食とみられる局部腐食が発生してい るものと考えられた，そこで， $E_{\text {corr }}+200 \mathrm{mV}$ まで EIS 測定 を行った試料の表面を目視により観察した.

Fig. 12 にEIS 測定後の試料外観写真を示した。（a）には AZ31W，(b)には AZ61W，(c)には AZ91Wのものを示した. Fig. 12(b)，(c)でそれぞれ示した AZ61W および AZ91Wの 表面にははっきりとした孔食の形態が観察され，Fig. 12(a) で示した AZ31W の表面には島状に堆積したフレーク状の腐 食生成物層が観察され，他の (b)，(c)では観察されなかっ た。ここで，前述のように $\mathrm{AZ} 31 \mathrm{~W}$ は $E_{\text {corr }}+200 \mathrm{mV}$ で電流

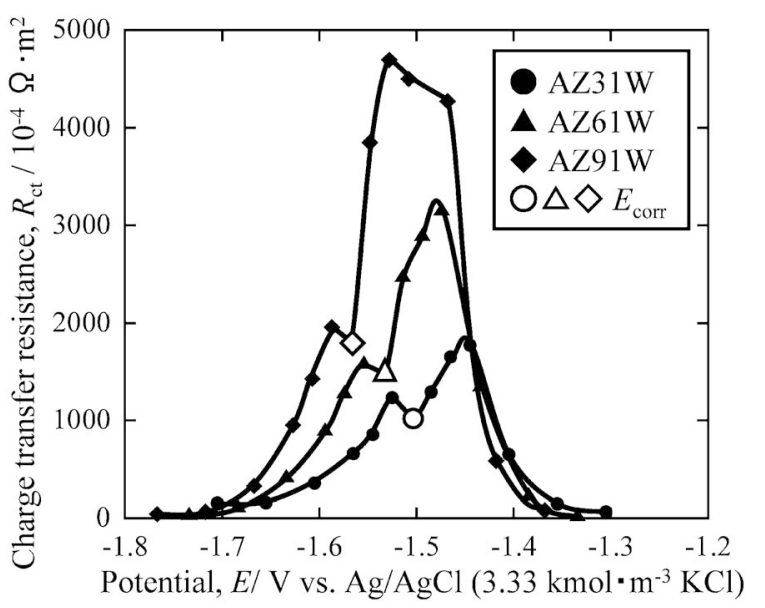

Fig. 11 Influence of potential on charge transfer resistance of AZ series Mg alloys.
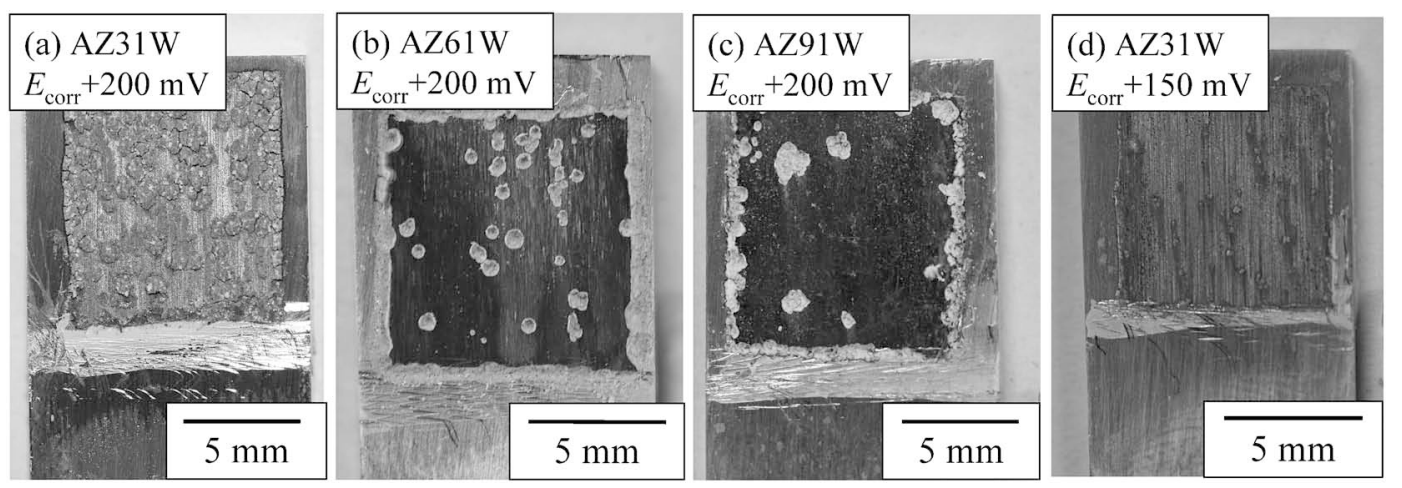

Fig. 12 Corrosion surface appearance of $\mathrm{AZ}$ series $\mathrm{Mg}$ alloys after measured EIS test under various potentials. (a) $\mathrm{AZ} 31 \mathrm{~W}, E_{\text {corr }}$ $+200 \mathrm{mV}$, (b) AZ61W, $E_{\text {corr }}+200 \mathrm{mV}$, (c) AZ91W, $E_{\text {corr }}+200 \mathrm{mV}$, (d) $\mathrm{AZ31W,} E_{\text {corr }}+150 \mathrm{mV}$. 
密度が他の 2 合金と比較して減少する傾向が確認された. すなわち，この電流密度の減少は合金表面に堆積した腐食生 成物に起因していると考えられる。そこで，AZ31Wについ ては $E_{\text {corr }}+150 \mathrm{mV}$ まで EIS 測定を行った後の試料表面に ついても Fig. $12(\mathrm{~d})$ に示した. $E_{\text {corr }}+150 \mathrm{mV}$ まで EIS 測定 を行った AZ31W の試料表面には Fig. 12(a)で観察された腐 食生成物層よりも小さな腐食生成物層が確認された。一方, この腐食生成物層を機械的に除去すると孔食発生が見られ た。これは， AZ31Wも他の 2 合金と同様，孔食が発生して いることが示唆される。しかしながら，AZ31W は他の 2 合 金に比べ，耐食性に劣ることから，溶解速度の増加によって 孔食表面での腐食生成物の堆積が顕著に現れたものと推定さ れる。

Fig. 13 に $C_{\mathrm{dl}}$ に及ぼす電位の影響を示した。 $\mathrm{A} Z 61 \mathrm{~W}$ およ び $\mathrm{AZ} 91 \mathrm{~W}$ は電位の変化によらず $C_{\mathrm{dl}}$ の值は $7 \times 10^{-2} \mathrm{~F} \cdot \mathrm{m}^{2}$ 程度とほぼ一定であった。一方，AZ31W は $E_{\text {corr }}$ では $8.5 \times$ $10^{-2} \mathrm{~F} \cdot \mathrm{m}^{2}$ であったが，アノード反応領域で $C_{\mathrm{d} 1}$ の大幅な上

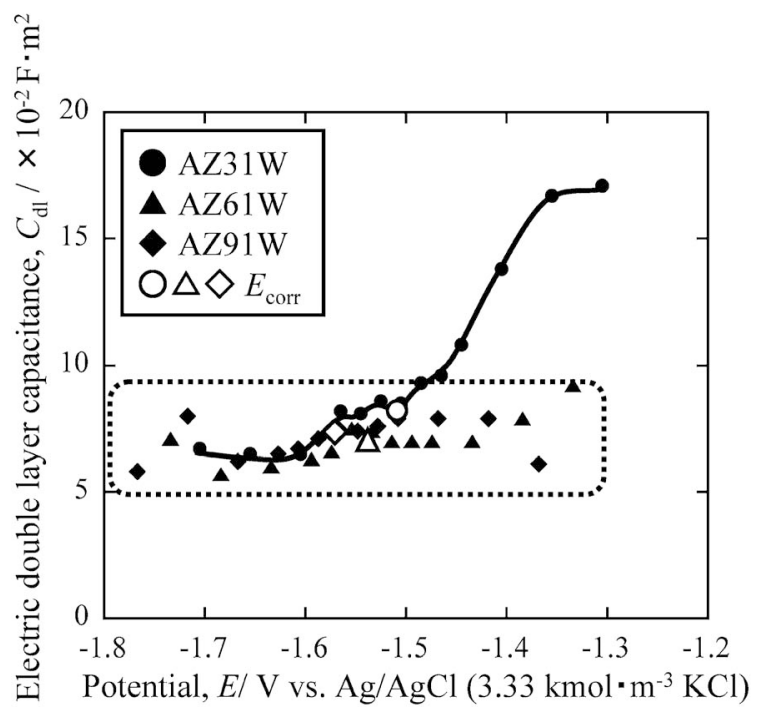

Fig. 13 Influence of potential on electric double layer capacitance of $\mathrm{AZ}$ series $\mathrm{Mg}$ alloys.
昇が確認され， $E_{\text {corr }}+200 \mathrm{mV}$ では $17.1 \times 10^{-2} \mathrm{~F} \cdot \mathrm{m}^{2}$ であっ た.この $C_{\mathrm{d} 1}$ の傾向は先に Fig. 12 で示した試料表面での腐 食生成物の堆積による傾向と一致していたため, この腐食生 成物の堆積が $C_{\mathrm{dl}}$ に影響を与えているものと考えられる.

Fig. 14 に $\tau_{0}$ に及ぼす電位の影響を示した. 各試料の $\tau_{0}$ はカソード反応領域である $E_{\mathrm{corr}}-20 \mathrm{mV}$ で值が上昇し, $E_{\text {corr }}+60 \mathrm{mV}$ 付近で最大值を示した。この傾向は前述した $R_{\mathrm{ct}}$ に及ぼす電位の影響の傾向と非常に良く一致しており, $\tau_{0}$ は $R_{\mathrm{ct}}$ に依存するものと考えられる. 一方, アノード反応 領域では AZ31W が右側に張り出した曲線形状を示した.こ れは，先に Fig. 13 で示した $C_{\mathrm{dl}}$ の影響を受けているものと 考えられる.

\section{4 乾湿繰返し試験}

以上の電気化学的試験によって得られた $A Z$ 系合金の耐食 性に及ぼす $\mathrm{Al}$ 含有量の影響を試料側から確認するため, 乾 湿繰返し試験を行った.

Fig. 15 に試験後の試料外観写真を示した.（a)はAZ31W, (b)は AZ61W，(c)はAZ91Wのものをそれぞれ示している.

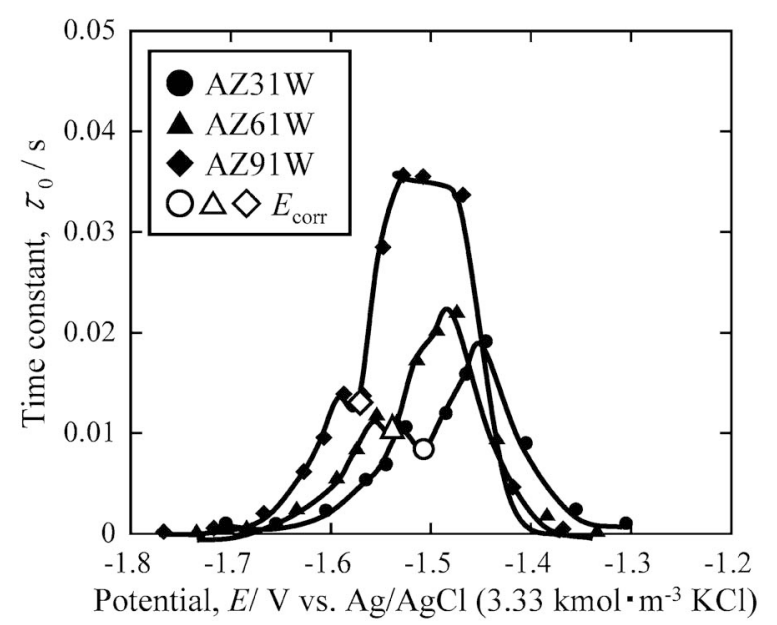

Fig. 14 Influence of potential on time constant of $A Z$ series $\mathrm{Mg}$ alloys.
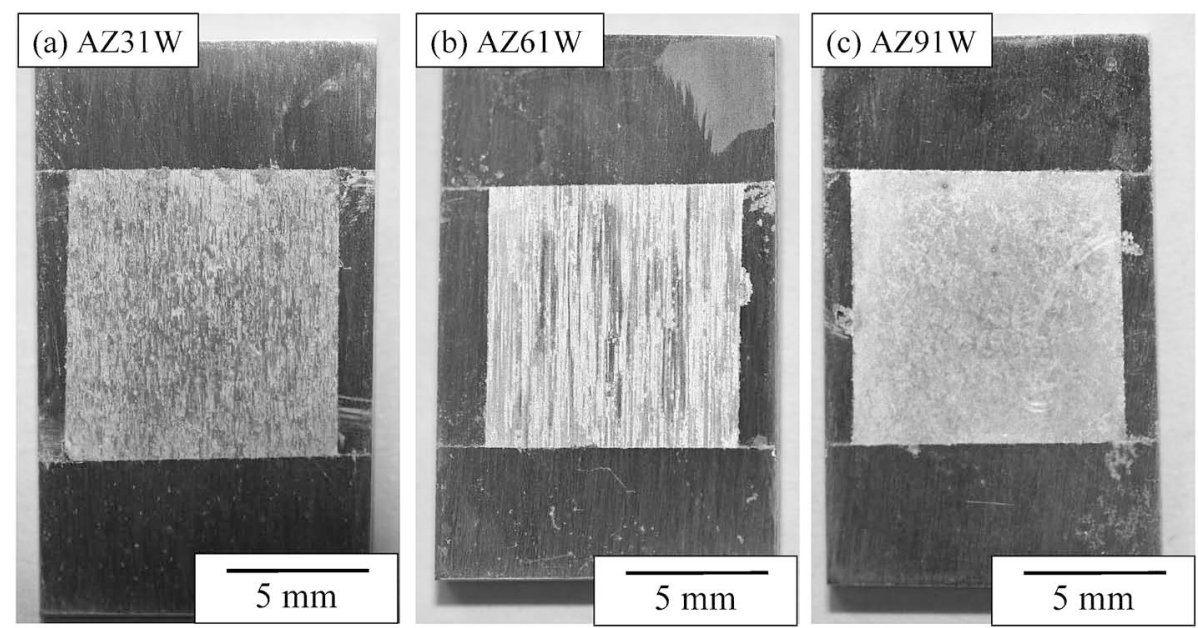

Fig. 15 Corrosion surface appearance of AZ series $\mathrm{Mg}$ alloys after alternate wetting and drying test. (a) AZ31W, (b) AZ61W, (c) AZ91W. 
AZ61W および AZ91W の表面には保護皮膜が形成されてお り，AZ61Wは保護皮膜が破れた形態を示した。一方， AZ31W には表面に腐食生成物が堆積している. 前述の電気 化学的な測定によって得られた各種腐食特性と良い一致を示 していると考えられる.

\section{4. 結言}

本報の主要な結果を要約すると次の通りである.

(1) 分極曲線測定および $E_{\text {corr }}$ での EIS 測定の結果より, $\mathrm{Al}$ 含有量の増加に伴い $I_{\text {corr }}$ が大きく減少し, $R_{\mathrm{ct}}$ が増加した ことから, AZ 系合金の自然浸漬環境下における耐食性向上 には $\mathrm{Al}$ の含有が有効である.

（2）各種電位に規制した EIS 測定の結果より，AZ 系合金

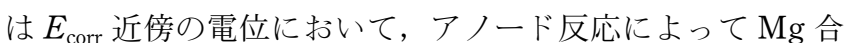
金表面に保護性の皮膜が形成し，その保護皮膜の特性は $\mathrm{Al}$ 含有量の増加に伴い，その保護性が向上する.

(3) 各種電位に規制した EIS 測定の結果および測定後の 試料表面観察より，上記 ${ }^{2}$ によって形成された保護皮膜は局 所的に破壊され，孔食が発生するが，中でも AZ31W 合金は 耐食性に劣ることによる溶出速度の増加によって腐食生成物 が堆積する。

\section{文献}

1) S. Sunada, T. Kawamura, K. Kondo, H. Notoya and K. Majima: J. Jpn. Soc. Powder Powder Metallurgy, 54 (2007) 658-664.

2) M. Fukuzumi, Y. Kaneko and K. Majima: J. Jpn. Soc. Powder Powder Metallurgy, 50(2002) 41-44.

3) N. Hara, D. Kagaya and N. Akao: Passivation of Metals and Semiconductors, and Properties of Thin Oxide Layers, A Selection of Papers from the 9th International Symposium, Paris, France, 27 June-1 July 2005, ed. by P. Marcus and V. Maurice, (Elsevier, 2006) pp. 217-223.

4) S. Sugimoto: Kinzoku hyomen gijyutsu, 32 (1981) 355-365.

5) K. Sugimoto: The Japan Institute of Metals (2003) 134-138.

6) K. Sugimoto and M. Yuki: J. Japan Inst. Metals 46 (1982) 11561163.

7) I. Epelboin, M. Keddam and J. C. Lestrade: Faraday Disc. Chem. Soc., 56 (1974) 264-275.

8) I. Epelboin and M. Keddam: J. Electrochem. Soc., 117(1970) $1052-1056$

9) I. Epelboin, M. Keddam and H. Takenouti: Electrochemica Acta, 20 (1975) 913-916.

10) R. D. Armstrong: J. Electroanal. Chem. 22(1969) 49-53.

11) R. D. Armstrong and M. Henderson: J. Electroanal. Chem. 39 (1972) 81-90.

12) R. D. Armstrong and R. E. Firman: Electroanal. Chem. \& Interfacial Electrochem. 45(1973) 3-10

13) M. Keddam, O. R. Mattos and H. Takenouti: J. Electrochem. Soc. 128(1981) 257-266.

14) M. Keddam, O. R. Mattos and H. Takenouti: J. Electrochem. Soc. 128(1981) 266-274.

15) M. Keddam, J.-F. Lizee, C. Pallotta and H. Takenouti: J. Electrochem. Soc. 131 (1984) 2016-2024

16) Y. Hara: Japan Society of Corrosion Engineering, (2004) 19-28.

17) M. Itagaki and K. Watanabe: DENKI KAGAKU 65 (1997) 758764.

18) K. Sugimoto: Zairyo-to-Kankyo 48(1999) 673-680.

19) S. Sunada, T. Yamamoto, K. Majima and N. Nunomura: J. Jpn. Soc. Powder Powder Metallurgy 52 (2005) 551-561.

20) M. Itagaki and K. Watanabe: DENKI KAGAKU 65(1997) 758764. 